\title{
Hepatoprotective Potential of Trichosanthes dioica Roxb in Hepatotoxicity Induced by Simvastatin and its Consequences on Biochemical and Haematological Indices
}

\author{
Ramesh Kumar Gupta ${ }^{1,2 *}$, Sudhansu Ranjan Swain ${ }^{3}$, Jagannath Sahoo ${ }^{4}$, Amresh Gupta ${ }^{5}$, Sachin Chaudhary
}

\section{Ramesh Kumar Gupta1,2*, Sudhansu Ranjan Swain ${ }^{3}$, Jagannath Sahoo ${ }^{4}$, Amresh Gupta ${ }^{5}$, Sachin Chaudhary ${ }^{6}$}

'Sherwood College of Faculty of Pharmacy, Barabanki-225001, Uttar Pradesh, INDIA. ${ }^{2}$ S.R.M.S. College of Engineering and Technology, Bareilly-243202, Uttar Pradesh, INDIA. ${ }^{3}$ Moradabad Educational Trust Group of Institutions, Faculty of Pharmacy, Moradabad-244001, Uttar Pradesh, INDIA. ${ }^{4}$ KIET School of Pharmacy, Ghaziabad-201001, Uttar Pradesh, INDIA. ${ }^{5}$ Goel Institute of Pharmacy and Sciences, Lucknow-226024, Uttar Pradesh, INDIA. ${ }^{6}$ College of Pharmacy, University of Sharjah, Sharjah-27272, UNITED ARAB EMIRATES.

\section{Correspondence}

Ramesh Kumar Gupta

Sherwood College of Faculty of Pharmacy, Barabanki-225001, Uttar Pradesh, INDIA.

Phone no : 9451529612

E-mail: ram5880@gmail.com

History

- Submission Date: 17-01-2018;

- Review completed: 05-03-2018

- Accepted Date: 12-04-2018

DOI : 10.5530/pj.2018.4.120

Article Available online

http://www.phcogj.com/v10/i4

\section{Copyright}

(C) 2018 Phcog.Net. This is an openaccess article distributed under the terms of the Creative Commons Attribution 4.0 International license.

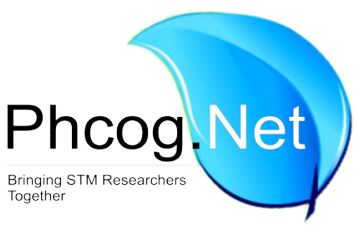

ABSTRACT

Objective:To evaluate hepatoprotective activity along with hematological and defensive recital of Trichosanthes dioica Roxb against simvastatin induced hepatotoxicity in experimental rodents. Methods: In the present study, in- vivo hepatoprotective effect of $50 \%$ methanolic fruit extract of Trichosanthes dioica Roxb (TME 200 and $400 \mathrm{mg} / \mathrm{kg}$ body weight) was evaluated using experimental model, simvastatin (20 mg/ $/ \mathrm{kg}$, p.o.), induced hepatotoxicity in experimental animals. The hepatoprotective activity was estimatedby interpreting using various biochemical parameters like SGOT, SGPT, ALP, total bilirubin, total protein and albumin along with the haematological and histopathological studies. Results: The treatment with TME significantly $(P<0.05-P<0.001)$ and dose-dependently reversed simvastatin induced elevation in serum level ofSGOT, SGPT, ALP, total bilirubin and restored the total protein and albumin level. Furthermore, TME also signify the blood parameters at dose of 1000 and $2000 \mathrm{mg} / \mathrm{kg}$ and restored the body defense mechanism. The histological examination revealed that TME at dose of $200 \mathrm{mg} / \mathrm{kg}$ showed regeneration of hepatocytes around central vein with near normal liver architecture. Conclusion: The results of this study exhibited liver protective effect of Trichosanthes dioica Roxb against simvastatin induced liver injury and there by scientifically support its traditional use.

Key words: Hepatocytes, Hepatotoxicity, Liver, Simvastatin, Trichosanthes dioica.

\section{INTRODUCTION}

Trichosanthes dioica Roxb, commonly known as parwal, belongs to cucurbitaceae family and is an annual or perennial herb distributed throughout India. Out of 20 species in India, two are cultivated as vegetable ( $T$. anguina and $T$. dioica). In Charaka Samhita, leaves and fruits are enlisted for treatment of alcoholism and jaundice. In Ayurveda, leaves are utilized as antipyretic, diuretic, cardiotonic, laxative, antiulcer. T. dioica accomodate numerous chemical constituents like vitamin A, saponins, tannins, alkaloids, mixture of novel peptides, proteins and vitamin C. ${ }^{1,2}$ Thevarious scientific research revealed that $T$. dioica exhibited antidiabetic, ${ }^{3}$ anti-hypercholesteraemic, ${ }^{4}$ hepatoprotective, ${ }^{5}$ anti-ulcer, ${ }^{6}$ immunomodulatory, ${ }^{7}$ antimicrobial, ${ }^{8}$ antioxidant, ${ }^{9}$ anti-diarrheal, ${ }^{10}$ nephroprotective, ${ }^{11}$ and wound healing activity. ${ }^{12}$

HMG CoA reductase inhibitors (Simvastatin) are effective in reducing cardiovascular mortality and are widely prescribed around the globe. More than 145 million patients were prescribed with statins in United States in 2005. The use of statins is increasing day by day, although liver toxicity has been a concern since their initial introduction. ${ }^{13}$ No scientific results are available affirming hepatoprotective potential of Trichosanthes dioica Roxb against hepatotoxicity induced by simvastatin. Hence, present investigation was designed to demonstrate hepatoprotective activity of Trichosanthes dioica Roxb against simvastatin induced liver toxicity.

\section{MATERIALS AND METHODS}

Drugs and Chemicals

Simvastatin (Merck Pharmaceutical, India). All chemicals used were of analytical grade and procured from Sigma Chemicals Co., USA and Qualigens fine chemicals, Mumbai, India.

\section{Collection and authentication of plant}

Fresh and matured fruits of T. dioica were purchased from local market of Lucknow, India in August 2016. The plant material was identified and authenticated by National Botanical Research Institute, Lucknow, India.

\section{Extraction of plant material}

The fruits of $T$. dioica were dried and powdered. The powdered plant material was macerated with petroleum ether; the marc was exhaustively extracted with of $50 \%$ methanol for three days. The extract was dried by rotator evaporator (IKA, Germany) under reduced pressure and procured in 
Gupta et al.: Consequences of T. dioica on Biochemical and Haematological Indices.

desiccator. The $\%$ yield was discovered to be $0.75 \%$. $1 \%$ Tween- 80 was used to prepare extract suspension of desirable concentration needed for pharmacological studies.

\section{Phytochemical investigation}

The methanolic extract of T. dioica fruits were subjected to preliminary phytochemical screening for detecting the presence or absence of active phytochemical constituents. ${ }^{14,15}$

\section{Animals}

Wistar rats weighing (150-170 g) of either sex were procured from Animal house of College of Pharmacy, Shri Ram Murti Smarak College of Engineering and Technology, Bareilly, India. They were kept in departmental animal house in well cross ventilated room at $22 \pm 2^{\circ} \mathrm{C}$ with light and dark cycles of $12 \mathrm{~h}$ for 1 week before and during the experiments. The experimental protocols were approved by Institutional Animal Ethical Committee, India (Reg. No. 715/02/CPCSEA).

\section{Acute toxicity study}

Acute toxicity study was performed according to OECD guidelines 423 . Albino mice (20-25 g) were divided into five groups with 5 mice in each. Group-I numbered as control received distilled water orally. Group-II, III, IV, and V were administered $T$. dioica extract at a dose of 5, 50, 300, $2000 \mathrm{mg} / \mathrm{kg}$, orally, respectively. The animals were noticed for toxicity sign or mortality every $24 \mathrm{~h}$, daily for 2 weeks. ${ }^{16}$

\section{Experimental design}

Wistar rats were divided into five different groups, each group having 6 rats. Group I received distilled water only for 30 days. Group II rats charged with simvastatin $(20 \mathrm{mg} / \mathrm{kg}$, p.o.) alone for 30 days orally. Group III and IV rats received simvastatin along with $T$. dioica fruits extracts $(200 \mathrm{mg} / \mathrm{kg}$ and $400 \mathrm{mg} / \mathrm{kg}$, p.o. respectively) for 30 day and Group V rats received simvastatin along with silymarin $(20 \mathrm{mg} / \mathrm{kg}$, p.o. $)$ for 30 days. On the $31^{\text {th }}$ day, blood samples were collected, and all the animals were sacrificed by cervical dislocation under mild ether anesthesia and liver sample were harvested, rinsed in saline and stored at $-80^{\circ} \mathrm{C}$ for further biochemical analysis. ${ }^{17}$

\section{Evaluation of liver protective activity}

The collected blood was allowed to clot and serum was separated by centrifugation in a refrigerated tabletop centrifuge at $2500 \mathrm{rpm}$ for $15 \mathrm{~min}$ and the biochemical parameters like serum enzymes: Serum glutamic oxaloacetic transaminase (SGOT, U/L), serum glutamic-pyruvic transaminase (SGPT, U/L), ${ }^{18}$ alkaline phosphatase (ALP, U/L), ${ }^{19}$ total bilirubin $(\mathrm{mg} / \mathrm{dL}),{ }^{20}$ total protein and albumin were evaluated. ${ }^{21,22}$

\section{Evaluation of hematological parameter}

Red blood cell (RBC) count, haemoglobin (Hb), white blood cell (WBC) count, platelet (PLT) and lymphocytes were determined by the fully automated hematology analyzer (XP 100 Hematology Analyzer, Transasia Bio-Medicals Ltd., India).

\section{Histopathological studies}

For histopathological inspection, the liver tissues were affixed with 10\% phosphate buffered neutral formalin, dehydrated in graded (50-100\%) alcohol and embedded in paraffin. fine sections $(5 \mu \mathrm{M})$ were cut and stained with routine hematoxylin and eosin stain for photo microscopic analysis. All the slides were studied under a light microscope for any histological destruction and protection.

\section{Statistical analysis}

The statistical comparison between the groups were made by One Way Analysis of Variance (ANOVA) and followed by Student-Newman-Keuls test. The value $p<0.05$ was considered statistically using, Graph Pad
Prism 5.03 Software. The values were represented as mean \pm SEM for six rats.

\section{RESULTS}

\section{Phytochemical screening}

Phytochemical screening showed the presence of tannins, alkaloids, carbohydrates, flavonoids, glycosides and steroids as documented in Table 1.

\section{Acute toxicological outcome}

The methanolic extract of T. dioica at doses of 200 and $400 \mathrm{mg} / \mathrm{kg}$ body weight does not produce any toxic outcome. Therefore, these doses were selected for hepatoprotective studies.

\section{Effect of TME on serum hepatic parameters}

The outcome of $T$. dioica fruits extract dose was investigated on liver serum markers like SGOT, SGPT, ALP, bilirubin (BLB), total protein (TP) and albumin (ALB) level. Hepatic abrasion due to dose of simvastatin generate significant elevation in marker enzymes as SGOT by $336.5 \%$, SGPT by $135.7 \%$, ALP by $144 \%$, BLB by $39 \%$, and demotion in level of TP by $48.3 \%$ and ALB by $32.5 \%$ when compared to control (Group I). The dose of extract, TME 200 (Group III) and TME 400 (Group IV) declined the elevated level of SGOT (10.19\%, $\mathrm{P}<0.01$, 66.3\%, $\mathrm{P}<0.001)$, SGPT (15.41\%, $\mathrm{P}<0.01,73.2 \%, \mathrm{P}<0.001)$, ALP $(7.30 \%$, $\mathrm{P}<0.05,29.68 \%, \mathrm{P}<0.001)$, $\mathrm{BLB}(12.64 \%, \mathrm{P}<0.01,53.12 \%, \mathrm{P}<0.001)$ and promote the level of TP (17.94\%, ns, 37.25\%, $\mathrm{P}<0.01)$, ALB $(21.61 \%$, $\mathrm{P}<0.001,26.36 \%, \mathrm{P}>0.001)$ respectively as compared to group II. Similarly, silymarin decreased SGOT by $(120.6 \%, \mathrm{P}<0.001)$, SGPT $(110.1 \%$, $\mathrm{P}<0.001)$, ALP $(105 \%, \mathrm{P}<0.001), \mathrm{BLB}(216 \%, \mathrm{P}<0.001)$ and increased TP by $(42.85 \%, \mathrm{P}<0.001)$, ALB $(30.57, \mathrm{P}<0.001)$ as compared to group II. The results are tabulated in Table 2 .

\section{Effect of TME on body weight and liver weight}

The effect of different doses of TME on body weight and liver weight were studied (Table 3). In Group II body weight decreased by $5.845 \%$ while liver weight increased by $26.36 \%$. Animal Treated with TME at the doses of 200 and $400 \mathrm{mg} / \mathrm{kg}$ (Group III and IV) significantly increased in body weight by $2.15 \%, 3.81 \%$ respectively while liver weight was decreased by $1.01 \%$ and $8.56 \%$ respectively.

\section{Effect of TME on blood parameters}

The outcome in (Table 4) showed a significant change in RBC, Hb, PLT, WBC, and \% Lymphocytes counts. RBC PLT, WBC, and \% Lymphocytes counts significantly increased at the dose of 1000 and $2000 \mathrm{mg} / \mathrm{kg}$, while $\mathrm{Hb}$ count non-significantly increases at the dose of $1000 \mathrm{mg} / \mathrm{kg}$ as compared to control group. Hb, PLT, WBC and \% Lymphocytes counts significantly increased at the dose of $4000 \mathrm{mg} / \mathrm{kg}$, whereas RBC's count non-significantly increases at the dose of $4000 \mathrm{mg} / \mathrm{kg}$ when compared to the control group.

\section{Histopathological observations}

The histological explanation (Figure 1) support the results obtained from serum enzyme assays. Liver sections of control rats showed normal hepatic cells with well-preserved cytoplasm and well brought out central vein. Simvastatin $(20 \mathrm{mg} / \mathrm{kg}$ ) treated rats (Group II), displayed the massive fatty changes, necrosis, central vein congestion, ballooning degeneration, and the loss of cellular boundaries, whereas TME $200 \mathrm{mg} / \mathrm{kg}$ treated groups (Group III) showed mild congestion in central vein with less fatty changes, mild necrotic cells, with minimal inflammatory conditions and less infiltration of the leucocyte's while TME $400 \mathrm{mg} / \mathrm{kg}$ treated group (Group IV) showed regeneration of hepatocyte around central vein with near normal liver architecture, prominent nucleus and possessing maximum hepatoprotective action. Rats in (Group V) exhibited well 
brought out central vein, hepatic cell with well-preserved cytoplasm, prominent nucleus.

\section{DISCUSSION}

The WHO survey confirmed that $70-80 \%$ of the world population rely on noncommercial medicine from herbal sources in primary health care units. ${ }^{23}$ The results of the present study clearly indicated hepatoprotective effects of the methanolic fruits extract of Tricoxanthes dioca against simvastatin induced liver toxicity in rats. Liver is a vital organ within the body, playing essential role in metabolic homeostasis and detoxification of variety of drugs and xenobiotic. ${ }^{24}$ Assessment of liver function can be performed by estimating the activities of serum SGOT, SGPT,

Table 1: Preliminary phytochemical analysis of $T$. dioica fruit extract.

\begin{tabular}{cccc}
\hline S.No & Name of test & Constituents & Inference \\
\hline 1 & Ferric Chloride \& Gelatin test. & Tannin & + \\
2 & Mayers\&Wagners Test. & Alkaloids & + \\
3 & Benedict's test. & Carbohydrates & ++ \\
4 & Ferric Chloride \&Shinoda Test. & Flavonoids & + \\
5 & Keller Killiani\& Bromine water test. & Glycosides & - \\
6 & Salkowaski Test. & Steroids & + \\
\hline
\end{tabular}

“+” means present.

Table 2: Effect of TME on serum SGOT, SGPT, ALP, BLB, TP and ALBagainst simvastatin induced liver toxicity in rats.

\begin{tabular}{ccccccc}
\hline Groups & SGOT & SGPT & ALP & BLB & TP & ALB \\
\hline Control & $31.2 \pm 1.5$ & $41.3 \pm 2.1$ & $87.32 \pm 3.2$ & $0.2 \pm 0.01$ & $6.2 \pm 0.6$ & $3.6 \pm 0.01$ \\
SIM & $136.2 \pm 4.3^{\dagger}$ & $97.35 \pm 3.4^{\dagger}$ & $213.1 \pm 4.2^{\dagger}$ & $0.98 \pm 0.02^{\dagger}$ & $3.2 \pm 0.4^{\dagger}$ & $2.43 \pm 0.02^{\dagger}$ \\
TME200 & $123.6 \pm 3.4^{\mathrm{b}}$ & $84.35 \pm 3.1^{\mathrm{b}}$ & $198.6 \pm 4.1^{\mathrm{a}}$ & $0.87 \pm 0.04^{\mathrm{b}}$ & $3.9 \pm 0.3^{\mathrm{ns}}$ & $3.1 \pm 0.01^{\mathrm{c}}$ \\
TME400 & $81.9 \pm 3.1^{\mathrm{c}}$ & $56.2 \pm 2.9^{\mathrm{c}}$ & $164.32 \pm 3.2^{\mathrm{c}}$ & $0.64 \pm 0.03^{\mathrm{c}}$ & $5.1 \pm 0.2^{\mathrm{b}}$ & $3.3 \pm 0.02^{\mathrm{c}}$ \\
SYL 20 & $61.74 \pm 2.9^{\mathrm{c}}$ & $46.32 \pm 2.1^{\mathrm{c}}$ & $103.5 \pm 3.6^{\mathrm{c}}$ & $0.31 \pm 0.02^{\mathrm{c}}$ & $5.6 \pm 0.4^{\mathrm{c}}$ & $3.5 \pm 0.02^{\mathrm{c}}$ \\
\hline
\end{tabular}

Values are mean \pm S.E.M. of 6 rats in each group, ns: non-significant.

P values: ${ }^{\dagger}<0.001$ compared with respective control group I.

P values: ${ }^{\mathrm{a}}<0.05,{ }^{\mathrm{b}}<0.01,{ }^{\mathrm{c}}<0.001$ compared with group II.

Table 3: Effect of TME on body weight and liver weightagainst simvastatin induced liver toxicity in rats.

\begin{tabular}{cccc}
\hline S.No & Treatment & Body weight $(\mathbf{g})$ & Liver weight $(\mathbf{g})$ \\
\hline 1 & Control & $172.8 \pm 1.2$ & $6.42 \pm 0.01$ \\
2 & SIM & $162.7 \pm 1.3^{\dagger}$ & $7.92 \pm 0.02^{\dagger}$ \\
3 & TME200 & $166.2 \pm 1.3^{\mathrm{ns}}$ & $7.84 \pm 0.03^{\mathrm{b}}$ \\
4 & TME400 & $168.9 \pm 1.4^{\mathrm{b}}$ & $7.24 \pm 0.02^{\mathrm{c}}$ \\
5 & SYL20 & $170.8 \pm 1.1^{\mathrm{c}}$ & $6.98 \pm 0.01^{\mathrm{c}}$ \\
\hline
\end{tabular}

Values are mean \pm S.E.M. of 6 rats in each group, ns: non-significant.

P values: ${ }^{\dagger}<0.001$ compared with respective control group I.

P values: ${ }^{\mathrm{a}}<0.05,{ }^{\mathrm{b}}<0.01,{ }^{\mathrm{c}}<0.001$ compared with group II.

Table 4: Effect of TME on blood parameters against simvastatin induced liver toxicity in rats.

\begin{tabular}{ccccc}
\hline Parameter & Control & $1000 \mathrm{mg} / \mathrm{kg}$ & $2000 \mathrm{mg} / \mathrm{kg}$ & $4000 \mathrm{mg} / \mathrm{kg}$ \\
\hline $\mathrm{RBC}\left(\mathrm{x} 10^{12}\right)$ & $7.6 \pm 0.1$ & $8.1 \pm 0.12^{\mathrm{a}}$ & $8.4 \pm 0.13^{\mathrm{c}}$ & $7.9 \pm 0.16^{\mathrm{ns}}$ \\
$\mathrm{Hb}(\mathrm{g} / \mathrm{dL})$ & $13.01 \pm 0.2$ & $13.91 \pm 0.3^{\mathrm{ns}}$ & $14.6 \pm 0.4^{\mathrm{a}}$ & $14.4 \pm 0.5^{\mathrm{a}}$ \\
$\mathrm{PLT}\left(\mathrm{x} 10^{9} / \mathrm{L}\right)$ & $613.2 \pm 5.6$ & $634.6 \pm 6.2^{\mathrm{a}}$ & $645.2 \pm 4.6^{\mathrm{b}}$ & $653.5 \pm 5.1^{\mathrm{c}}$ \\
$\mathrm{WBC}\left(\mathrm{x} 10^{9}\right)$ & $8.1 \pm 0.12$ & $9.2 \pm 0.2^{\mathrm{a}}$ & $11.5 \pm 0.6^{\mathrm{c}}$ & $10.01 \pm 0.3^{\mathrm{b}}$ \\
Lymphocytes $(\%)$ & $41.2 \pm 2.1$ & $50.3 \pm 3.2^{\mathrm{a}}$ & $54.2 \pm 3.1^{\mathrm{a}}$ & $58.6 \pm 3.5^{\mathrm{b}}$ \\
\hline
\end{tabular}

Values are mean \pm S.E.M. of 6 rats in each group, ns: non-significant.

$P$ values: ${ }^{\dagger}<0.001$ compared with respective control group I.

P values: ${ }^{\mathrm{a}}<0.05,{ }^{\mathrm{b}}<0.01,{ }^{\mathrm{c}}<0.001$ compared with group II. 

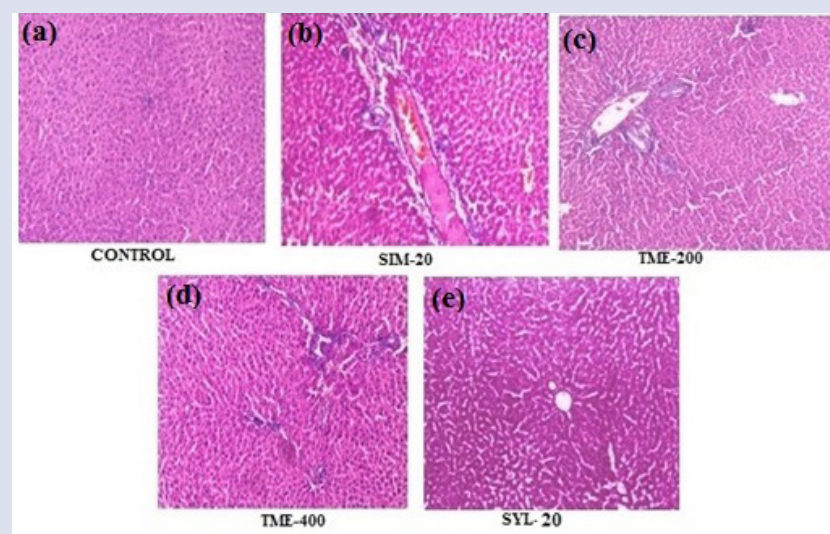

Figure 1: Histopathology of H\&E stained sections of liver at 250X.

(a) Liver sections of normal control rats showed the normal hepatic cells with well-preserved cytoplasm; well brought out central vein.

(b) Liver section of SIM20 showed the massive fatty changes, necrosis, central vein congestion, ballooning degeneration, and the loss of cellular boundaries.

(c) Liver section of TME 200 showed mild congestion in central vein with less fatty changes, mild necrotic cells, with minimal inflammatory conditions, less infiltration of the leucocytes.

(d) Liver section of TME400 showed regeneration of hepatocyte around central vein with near normal liver architecture, prominent nucleus and nucleolus and possessing maximum hepatoprotective action.

(e) Liver section of rats SYL20 showed well brought out central vein, hepatic cell with well-preserved cytoplasm, prominent nucleus and nucleolus.

ALP, total bilirubin, albumin and total proteins, which are originally present in higher concentrations in hepatocytes. During liver disease, these enzymes leak into the bloodstream in conformity with the extent of liver damage..$^{25}$ Bilirubin is an index of liver function and its elevated level indicate damage to the liver and bile duct. ${ }^{26}$ Liver damage induced by simvastatin represents disturbances of metabolism of liver cells that leads to distinctive changes in the liver serum markers. The increased levels of hepatic serum markers like SGOT, SGPT, ALP, total bilirubin and decreased in the albumin, was observed in simvastatin treated animals; this may bedue to the changes in the cell membrane permeability indicating severity of hepatocellular damage. ${ }^{27,28}$ The animals treated with methanolic extract of T. dioica significantly reduced the levels of SGOT, SGPT, ALP, total bilirubin while increase total protein and albumin levels in dose dependent manner as compared with simvastatin as well as silymarin treated animals. Blood parameters dispense valuable data regarding health of animals. ${ }^{29}$

Administration of the plant extract resulted in significant increment inHb, PLT, WBC and \% Lymphocytes counts at the dose of $4000 \mathrm{mg} / \mathrm{kg}$. $\mathrm{RBC}$ and $\mathrm{Hb}$ are vital in transporting respiratory gases. The increment in levels of RBC and $\mathrm{Hb}$ implies that extract did not adversely affect oxygen carrying capacity of the blood and the amount of oxygen delivered to tissues, therefore can be used in anaemia. ${ }^{30}$ The significant increment in the platelet count following administration of plant extract is the indication of stimulation of thrombopoietin creation as it has hemostatic capability of the blood and upholding blood clotting mechanism. ${ }^{31}$ Inflammatory response is characterized by the involvement of WBC. In this study, the incrementin level of WBC indicates the stimulation of immune system, in retort to toxic environment. ${ }^{32}$ Lymphocytes are the key cells of the immune system and elevation in its level indicates pathogenic attack and play the chief role in body defense mechanisms. ${ }^{33,34}$ Increased level of WBC's and Lymphocytes suggesting that the TME extract challenge the immune system of the animals. Liver protective outcome of TME was further investigated by histopathological study. TME at different dose levels offers liver protection, but $400 \mathrm{mg} / \mathrm{kg}$ is more effective than all other inferior doses. As demonstrated in the present study, administration of simvastatin significantly elevated serum levels of hepatic enzymes, and that representing significant hepatocellular harm. Thus, our study confirmed the hepatoprotective potential of Trichosanthes dioica Roxb against simvastatin induced liver toxicity in rats. In fact, activity of Trichosanthes dioica Roxb is quite like silymarin, as reference hepatoprotective agent.

\section{ACKNOWLEDGEMENT}

The authors are thankful to Shri Dev Murti, Chairman, Shri Ram Murti Smarak College of Engineering and Technology, Bareilly, Uttar Pradesh, India for providing facilities to carry out the research.

\section{CONFLICT OF INTEREST}

No conflict of interest associated with this research work.

\section{ABBREVIATIONS}

SGOT: Serum glutamic oxaloacetic transaminase; SGPT: Serum glutamic pyruvic transaminase; ALP: Alkaline phosphatase; SEM: structural equation modeling; SIM: Simvastatin; SLY: Silymarin.

\section{REFERENCES}

1. Toshniwal V, Misal R, Metkar V, Toshniwal A, Patil G, Wandhare M. Trichosanthes dioica Roxb. A Review. Asian J Pharm Inven. 2013;1:1-10.

2. Kumar N, Singh S, Manvi, Gupta R. Trichosanthes dioica Roxb. An overview. Pharmacogn Rev. 2012;6(11):61-7.

3. Rai PK, Jaiswal D, Rai DK, Sharma B, Watal G. Effect of water extract of Trichosanthes dioica fruits in streptozotocin induced diabetic rats. Indian $\mathrm{J}$ ClinBiochem. 2008;23(4):387-90

4. Sharmila BG, Kumar G, Rajasekhara PM. Cholesterol-lowering activity of the aqueous fruit extract of Trichosanthes dioica in normal and streptozotocin diabetic rats. J CliDia Res. 2007;1(6):561-9.

5. Ghaisas MM, Tanwar MB, Ninave PB, Navghare VV, Takawale AR, Zope VS, et al. Hepatoprotective activity of aqueous and ethanolic extract of $T$. dioica in ferrous sulphate induced liver injury. Pharmacologyonline. 2008;3:127-35.

6. Galani VJ, Goswami SS, Shah MB. Antiulcer Activity of PatolChurna against experimental Gastro-duodenal Ulcers in Rats. J Homeopat Ayurv Med. 2012;1(105):1-4.

7. Bhadoriyal SS, Mandoriya N. Immunomodulatory effect of Tricosanthes dioica Roxb. Asian Pac J Trop Biomed. 2012;2(2):S985-7.

8. Rai PK, Mehta S, Gupta RK, Watal G. A Novel Antimicrobial Agents Trichosanthes dioica. Int J Pharm Bio Sci. 2010;1(3):202-9.

9. Shivhare $Y$, Singh $P$, Rajak $H$, Patil UK, Pawar RS. Antioxidant potential of Trichosanthes dioica Roxb (fruits). Phcog J. 2010;2(6):107-11.

10. Akter S, Imam MZ, HasanSM, HossainMM, MazumderME, Rana MS. Antioxidant antidiarrhoeal and cytotoxic properties of aerial parts of Trichosanthes dioica Roxb. Am J Food Nutr. 2011;1(1):95-101.

11. Gupta RK, Swain SR, Murthy PN, Sahoo J, Verma P, Rao CV, et al. Nephroprotective potential of Trichosanthes dioica Roxb. leaves extract against Gentamicin induced Nephropathy in albino Rats. Asian J Pharm Health Sci. 2015;5(3):1300 05.

12. Shivhare Y, Singh P, Patil UK. Healing Potential of Trichosanthes dioica Roxb on Burn Wounds. Res J Pharmacol Pharmacodynamics. 2010;2(2):168-71.

13. Bharadwaj SS, Chalasani N. Lipid lowering agents that causes drug induced hepatotoxicity. Clin liver Dis. 2007;11(3):597-613.

14. Kumar AR, Subburathinam KM, Prabakar G. Phytochemical screening of selected medicinal plants of Asclepiadaceae family. Asian J Microbiol Biotechnol Environ Sci. 2007;9(1):177-80.

15. Chaudhary S, Negi A, Dahiya V. The study of in vitro antimicrobial activity andphytochemical analysis of some medicinal plants in chamoligarhwal region. Pharmacog J. 2010;2(12):481-5. 
16. Organization for Economic Cooperation and Development. OECD guidelines 423. Oral Toxicity Study in Rodents. OECD Guidelines for the Testing of Chemicals. 2001;423:1-8

17. Vaghasiya J, Rathod S, Bhalodia Y, Manek R, Malaviya S, JivaniN. Protective effect of polyherbal formulation on simvastatin hepatotoxicity in rats. J Young Pharmacists. 2009;1(1):57-62.

18. Reitman S, Frankel S. A colorimetric method for the determination of serum glutamate oxaloacetate transaminase. Am J Clin Pathol. 1957;28(1):56-63.

19. King J. The hydrolases-acid and alkaline phosphatases. In: Practical Clinical Enzymology. London: Nostrand Company Ltd. 1965;191-208.

20. Malloy HT, Evelyn KA. The determination of bilirubin with the photometric colorimeter. J Biol Chem. 1937;119(2):481-90.

21. Lowry OH, Rosebrough NJ, Farr AL. Protein measurement with the folin-phenol reagent. J Biol Chem. 1951;193(1):265-75.

22. Verma N, Singh AP, Amresh G, Sahu P, Rao CV. Protective effect of ethyl acetate fraction of Rhododendron arboretum flowers against carbon tetrachlorideinduced hepatotoxicity in experimental models. Indian J Pharmacol. $2011 ; 43(3): 291-5$.

23. Attar AMA, Taisan WA. Preventive effects of black seed (Nigella sativa) extract on Sprague dawley rats exposed to diazinon. Aust J Basic Appl Sci. 2010;4(5):957-68.

24. Shamsi BH, Sharifian A, Esmaeili S, Minaei B. Hepatoprotective herbs, avicenna viewpoint. Iran Red Crescent Med J. 2014;16(1):312-3.

25. Nkosi CZ, Opoku AR, Terblanche SE. Effect of pumpkin seed (Cucurbita pepo) protein isolate on the activity levels of certain plasma enzymes in $\mathrm{CCl}_{4}$-induced liver injury in low-protein fed rats. Phytother Res. 2005;19(4):341-5.

26. Rajesh KG, Achyut NK, Geeta W, Murthy PS, Ramesh C, Vibha T. Nutritional and hypoglycemic effect of fruit pulp of Annonasquamosa in normal healthy and alloxan-induced diabetic rabbits. Ann Nutr Metab. 2005;49(6):407-13.

27. Rao AS, Ahmed MF, Ibrahim M. Hepatoprotective activity of Melia azedarach leaf extract against simvastatin induced Hepatotoxicity in rats. J Appl Pharm Sci. 2012;02(07);144-8.

28. Irfan MA, Ahmed MF, Bakhtiary SA, Ibrahim M. Hepatoprotective activity of Leucas aspera Spreng against simvastatin induced hepatotoxicity in rats. Annals Phytomed. 2012;1(2):88-92.

29. Yahubu OE, Olawale O, Arowora KA, Imo C. Bicohemical changes in haematological and liver function parameters in intoxicated male albino rats reated with Hymenocardiaacida leaves ethanolic extract. Insight in Biomedicine. $2017 ; 2(2): 1-5$

30. Effiong GS, Akpan HD. The effect of Nauclealatifolia leaf extract on some biochemical parameters in streptozotocin diabetic rat models. J Med and Med Sci. 2015;6:47-52

31. Oyedeji KO, Bolarinwa AF. Effect of crude extract of Portulaca oleracea on haematological and biochemical parameters in albino rats. Afr J Biomed Res. 2012;15(1):41-7.

32. Eyong EU, Umoh IB, Ebong PE, Eteng MU, Antai AB, Akpa AO. Haematoxic effects following ingestion of Nigerian crude oil and crude oil polluted shellfish by rats. Niger J Physiol Sci. 2004;19(1-2):1-6.

33. De-Gruchy GC. Clinical haematology in Medical Practice. Blackwell Scientific Publication. Oxford: 1979;33-57.

34. Mbaka GO, Adeyemi OO, Oremosu AA. Acute and sub-chronic toxicity studies of the ethanol extract of the leaves of Sphenocentrum jollyanum (Menispermaceae). Agric Biol J N Am. 2010;1(3):265-72.

\section{GRAPHICAL ABSTRACT}

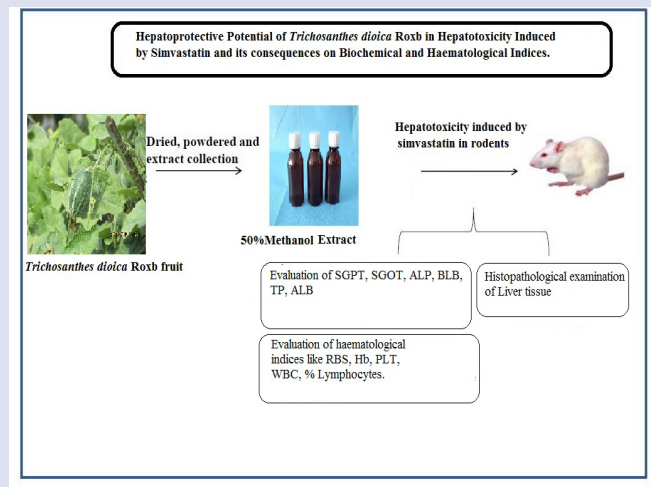

\section{SUMMARY}

- Hepatoprotective potential methanolic fruit extract of TrichosanthesdioicaRoxb was estimated along with its effect on biochemical and haematological indices in hepatotoxicity induced by simvastatin in rats. The results demonstrate the alterations in elevated levels ofSGOT, SGPT, ALP, total bilirubin and restored the total protein and albumin level. The histological study showed regeneration of hepatocytes around central vein with near normal liver architecture revealing hepatoprotective effect of fruit extract.

\section{ABOUT AUTHORS}

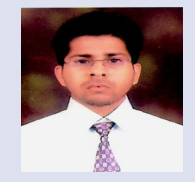

Ramesh Kumar Gupta: Asst. Professor, Sherwood College of Pharmacy, Barabanki.

Cite this article: Gupta RK, Swain SR, Sahoo J, Gupta A, Chaudhary S. Hepatoprotective Potential of Trichosanthes dioica Roxbin Hepatotoxicity Induced by Simvastatin and its consequences on Biochemical and Haematological Indices. Pharmacog J. 2018;10(4):720-4. 